\title{
The Utilization Kepok Fermented Banana Peels In Feed Against The Percentage Of Local Male Sheep Fat.
}

\author{
D. M. Ihsan ${ }^{1}$, S. Sepriadi ${ }^{1}$, N. Ginting ${ }^{1}$, Y. L.Henuk ${ }^{1}$, I. Sembiring ${ }^{1}$, G.A.W. \\ Siregar ${ }^{1}$, S. Sinulingga ${ }^{2}$ \\ ${ }^{1}$ Animal Production Study Program, Faculty of Agriculture, Universitas Sumatera Utara, \\ Medan, Indonesia \\ ${ }^{2}$ Goat Research Centre Sei Putih, Galang, Sumatera Utara, Indonesia
}

\begin{abstract}
This research aims to know the percentage of fat in local male sheep was given fermented kepok banana peelwaste using $\mathrm{EM}_{4}$. The research was using 20 rams local male sheep with an average of $12,30 \pm 1,77 \mathrm{~kg} / \mathrm{head}$. The design used was completely randomized desing (CRD) with 5 treatmens and 4 replications. With various treatmens consisting of T0 (40\% kepok banana peel without fermentation in ration); T1 (20\% kepok banana peel fermentation in ration); T2 (40\% kepok banana peel fermentation in ration); T3 (60\% kepok banana peel fermentation in ration). The results showed that the treatment had no significant effect $(\mathrm{P}>0,05)$ to the percentage of subcutaneous fat and percentage of heart fat, significant different effect $(\mathrm{P}<0,05)$ to the percentage of pelvic fat and show very different effect $(\mathrm{P}<0,01)$ to the percentage of kidney fat. The use of fermented kepok banana peels in local sheep feedpositive effect on increasing the percentage of kidney fat, pelvis, subcutaneous fat and heart, the use of fermented kepok banana peels by $60 \%$ in feed increases the percentage of kidney and pelvic fat.
\end{abstract}

Keyword: Banana peels fermentation, percentage of fat, local male sheep

Received [12 November 2019] | Revised [26 November 2019] | Accepted [31 Desember 2019]

\section{Introduction}

Forage is the main source of feed for sheep that determines the success of the farm. As it is known that forage productivity is seasonal where during the rainy season the abundance of forage availability, but in the dry season the availability of forage is very little or no, so that sheep farming can decrease its productivity.

To overcome this problem, it is necessary to find alternative feed alternatives to forage forage in the dry season. In this case, banana peel waste is an option that can be used as an alternative feed. Banana peel waste can be found in the food industry that uses Kepok banana as raw material. 
Sheep is a small ruminant livestock which in maintenance is not so difficult, this is because the sheep are relatively small and quickly mature so that they are automatically quite profitable because they can produce wool and meat [1].

Banana peel waste is organic waste that has nutritional content that can still be utilized. The main content that can be utilized is carbohydrate, carbohydrate content in banana peels is quite high at $18.5 \%$ [2].

Banana peels contain $59.00 \%$ carbohydrates, $0.90 \%$ crude protein, $1.70 \%$ crude fat, $31.70 \%$ crude fiber, and some mineral contents in it such as $78.10 \%$ potassium, $19.20 \%$ calcium, iron $24.30 \%$ and manganese $24.30 \%$ [3].

Fat is one of the groups included in the lipid group, which is an organic compound that is found in nature and is not soluble in water, but is soluble in non-polar organic solvents. Fat is a triglyceride compound from glycerol. In its formation, triglycerides are the result of the condensation process of one glycerol molecule and three fatty acid molecules (generally the three different fatty acids), which form one triglyceride molecule and one water molecule [4].

Fat is a network that is dynamic, many gather in the abdominal and kidney cavity walls. Laying fat first around the internal organs, kidneys and digestive organs then fat is stored in connective tissue around the muscles under the skin and between muscles [5].

Fat on the body of cattle is divided into subcutaneous (under the skin), under the stomach, in the muscles (intramuscular), more abdominal fat in rams and the more age the higher the amount [6]. Stated that higher carcass weight caused the percentage of meat or palm also to increase [7].

\section{Materials and Methods}

The research was using 20 rams local male sheep with an average of $12,30 \pm 1,77 \mathrm{~kg} / \mathrm{head}$. The design used was completely randomized desing (CRD) with 5 treatmens and 4 replications. Feed ingredients such as forage, banana peel, soybean meal, rice bran, cassava, palm kernel cake, molasses, minerals, EM4, medicines - worming, drinking water, and rodalone as disinfectants The tools used are 20 individual cages with $1 \times 1 \mathrm{~m} 2$ size, 20 buckets as a place to feed and 20 drinking containers, a scale with a capacity of $150 \mathrm{~kg}$ with a sensitivity of $50 \mathrm{~g}$, a scale with a capacity of $2 \mathrm{~kg}$ with a sensitivity of $10 \mathrm{~g}$ to weigh feed.

Table 1. Composition of Research Feed Ingredients

\begin{tabular}{lcccc}
\hline \multirow{2}{*}{ Feed of Ingrediens } & \multicolumn{5}{c}{ Treatment (\%) } \\
\cline { 2 - 5 } & $\mathrm{T} 0$ & $\mathrm{~T} 1$ & $\mathrm{~T} 2$ & $\mathrm{~T} 3$ \\
\hline $\begin{array}{l}\text { Kepok Banana Peels } \\
\text { Without Fermentation }\end{array}$ & 40,00 & 0 & 0 & 0 \\
\hline $\begin{array}{l}\text { Kepok Banana Peels } \\
\text { Fermentation }\end{array}$ & 0 & 20,00 & 40,00 & 60,00 \\
\hline Rice Bran & 12,00 & 35,00 & 20,00 & 7,00 \\
Palm Carnel Cake & 10,00 & 12,00 & 11,00 & 8,00 \\
Soy Bean Meal & 18,00 & 12,00 & 10,00 & 8,00 \\
Onggok & 14,00 & 15,00 & 13,00 & 11,00
\end{tabular}




\begin{tabular}{lcrrr} 
Molases & 5,00 & 5,00 & 5,00 & 5,00 \\
Premix & 1,00 & 1,00 & 1,00 & 1,00 \\
\hline Total & 100 & 100 & 100 & 100 \\
\hline Dry Ingredients (\%) & 59,03 & 73,19 & 59,23 & 45,20 \\
Crude Protein (\%) & 15,62 & 15,83 & 15,77 & 15,63 \\
Crude Fiber (\%) & 11,08 & 9,33 & 9,82 & 10,14 \\
Crude Fat (\%) & 4,87 & 5,37 & 5,36 & 5,47 \\
TDN & 60,99 & 64,38 & 63,07 & 61,67 \\
\hline
\end{tabular}

\subsection{Research methods}

The study was conducted experimentally using a completely randomized design (CRD) 4 treatments 5 replications. The treatments given are as follows: P0: 40\% kepok banana peel without fermentation in ration, $\mathrm{P} 1: 20 \%$ of kepok banana skin ferment in ration, $\mathrm{P} 2: 40 \%$ Kepok banana peel in the ration, P3: 60\% kepok banana skin ferment in ration.

Parameters of Research were percentage of subcutaneous fat obtained from the comparison of subcutaneous fat weight with carcass weight multiplied by $100 \%$, percentage of kidney fat obtained from the comparison of kidney fat weight with carcass weight times $100 \%$, percentage of pelvic fat obtained from the comparison of the weight of pelvic fat with carcass weight multiplied by $100 \%$, percentage of heart fat obtained from the comparison of heart fat weight with carcass weight times $100 \%$

\section{Results and Discussion}

\subsection{Percentage of Subcutaneous Fat}

Table 2. Average percentage of local male subcutaneous fat during the study (\%)

\begin{tabular}{|c|c|c|c|c|}
\hline \multirow{2}{*}{ Treatment } & \multicolumn{2}{|c|}{ Repetition } & \multirow{2}{*}{ Total } & \multirow{2}{*}{ Average } \\
\hline & 1 & 2 & & \\
\hline T0 & 1,16 & 0,99 & 2,15 & $1,07^{\mathrm{A}} \pm 0,12$ \\
\hline $\mathrm{T} 1$ & 1,26 & 1,19 & 2,45 & $1,22^{\mathrm{A}} \pm 0,15$ \\
\hline $\mathrm{T} 2$ & 1,08 & 1,24 & 2,32 & $1,16^{\mathrm{A}} \pm 0,11$ \\
\hline $\mathrm{T} 3$ & 1,14 & 1,34 & 2,48 & $1,24^{\mathrm{A}} \pm 0,14$ \\
\hline
\end{tabular}

Note: The same superscript in the same row and column shows no significant difference $(\mathrm{P}>0.05)$.

According to [8] subcutaneous fat is fat deposited under the skin. From the results of the study it was found that the highest average percentage of subcutaneous fat was found in P1 treatment (20\% of fermented kepok banana peels in rations) which was $1.22 \%$ and the lowest in P2 treatment (40\% of fermented kepok banana peels in ration) was equal to $1,16 \%$. This is consistent with the statement of [9] which states that the amount of fat in the body is the most diverse and highly dependent on the amount of feed consumed. [10] research results revealed that the percentage of subcutaneous fat is influenced by the amount of feed consumed. In addition, variations in body fat are caused by differences in body growth and development that depends on the nation, age, sex and background of feed. [11] stated that carcasses of rams lead to subcutaneous fat with increasing body weight.

The average percentage of sheep kidney fat given fermented kepok banana peels during the study ranged from 0.38 to $0.81 \%$ higher compared to the percentage of sheep kidney fat given kepok banana skin without fermentation that is equal to $0.49 \%$. 


\subsection{Percentage of Kidney Fat}

Table 3. Average percentage of local male kidney fat during the study (\%)

\begin{tabular}{|c|c|c|c|c|}
\hline \multirow{2}{*}{ Treatment } & \multicolumn{2}{|c|}{ Repetition } & \multirow{2}{*}{ Total } & \multirow{2}{*}{ Average } \\
\hline & 1 & 2 & & \\
\hline T0 & 0,50 & 0,48 & 0,98 & $0,49^{\mathrm{C}} \pm 0,01$ \\
\hline $\mathrm{T} 1$ & 0,41 & 0,36 & 0,77 & $0,38^{\mathrm{C}} \pm 0,04$ \\
\hline $\mathrm{T} 2$ & 0,51 & 0,66 & 1,17 & $0,58^{\mathrm{B}} \pm 0,11$ \\
\hline $\mathrm{T} 3$ & 0,78 & 0,85 & 1,63 & $0,81^{\mathrm{A}} \pm 0,05$ \\
\hline Total & 2,20 & 2,35 & & \\
\hline
\end{tabular}

Note: Different superscripts in the same row and column show very significant differences $(\mathrm{P}<0.01)$.

A very significant increase in the percentage of kidney fat is due to high feed consumption in the provision of fermented kepok banana peels. It is known that fermentation can increase fat in the substrate. The higher the proportion of kepok banana peels given, the higher the fat contained in the feed. This is in accordance with the opinion of [12] which states that microbes change carbohydrates in the media / substrate into fat which is then accumulated as cell fat.

\subsection{Percentage of Pelvic Fat}

Table 4. Average percentage of local male pelvic fat during the study $(\%)$

\begin{tabular}{|c|c|c|c|c|}
\hline \multirow{2}{*}{ Treatment } & \multicolumn{2}{|c|}{ Repetition } & \multirow{2}{*}{ Total } & \multirow{2}{*}{ Average } \\
\hline & 1 & 2 & & \\
\hline T0 & 1,19 & 1,16 & 2,35 & $1,17^{\mathrm{C}} \pm 0,02$ \\
\hline $\mathrm{T} 1$ & 1,58 & 1,45 & 3,03 & $1,51^{\mathrm{C}} \pm 0,09$ \\
\hline $\mathrm{T} 2$ & 1,72 & 2,10 & 3,82 & $1,91^{\mathrm{B}} \pm 0,27$ \\
\hline T3 & 1,90 & 2,16 & 4,06 & $2,03^{\mathrm{A}} \pm 0,18$ \\
\hline Total & 6,39 & 6,87 & & \\
\hline
\end{tabular}

Note: Different superscripts in the same row and column show significant differences $(\mathrm{P}<0.05)$.

The highest percentage of pelvic fat was found in P3 treatment (60\% of kepok banana skin fermentation in rations) which was $2.03 \%$ and the lowest in P0 treatment (40\% of kepok banana skin without fermentation in ration) was $1.51 \%$.

It is suspected that fat weight is influenced by the amount of food consumed, the energy content of the ration, and nutrition in the ration. This is consistent with the statement of [13] who concluded that kidney and pelvic fat is influenced by ration energy levels. [14] reports that omental fat, kidney fat, and pelvic fat are influenced by ration energy levels.

\subsection{Percentage of Heart Fat}

Table 5. Average percentage of local male heart fat during the study (\%)

\begin{tabular}{|c|c|c|c|c|}
\hline \multirow{2}{*}{ Treatment } & \multicolumn{2}{|c|}{ Repetition } & \multirow{2}{*}{ Total } & \multirow{2}{*}{ Average } \\
\hline & 1 & 2 & & \\
\hline T0 & 0.50 & 0.4 & 0.90 & $0,45^{\mathrm{A}} \pm 0,07$ \\
\hline $\mathrm{T} 1$ & 0.48 & 0.4 & 0.88 & $0.44^{\mathrm{A}} \pm 0.06$ \\
\hline $\mathrm{T} 2$ & 0.37 & 0.54 & 0.91 & $0,45^{\mathrm{A}} \pm 0,12$ \\
\hline T3 & 0.46 & 0.53 & 0.99 & $0,49^{\mathrm{A}} \pm 0,05$ \\
\hline Total & 1.81 & 1.87 & & \\
\hline
\end{tabular}


Note: The same superscript in the same row and column shows no significant difference $(\mathrm{P}>0.05)$.

The study found that the highest average percentage of heart fat was found in the P3 treatment ( $60 \%$ of the skin of Kepok banana fermented in rations), which was $0.49 \%$ and the lowest in the treatment of P1 (20\% of the skin of Kepok banana fermented on ration), that was $0.44 \%$.

There was a difference in the percentage of heart fat in sheep fed fermented kepok banana peels and unfermented fermented kepok banana peels. According to [15] states that sheep that get more food have more heart fat.

\section{Conclusion}

The use of fermented kepok banana peels in local sheep feed has a positive effect on increasing the percentage of kidney fat, pelvis, subcutaneous fat and heart. The use of fermented kepok banana peels by $60 \%$ in feed increases the percentage of kidney and pelvic fat.

\section{References}

[1] Murtidjo, B.A. 1992. Rearing Sheep. Kanisius, Yogyakarta.

[2] Gunawan. 2013. The Content and Benefits of Banana Skin. http://tanamobatherbal.blogspot.com/2013/02/kandungan-dan- beneficial-kulitpisang.html. Accessed 28 October 2013.

[3] Anhwange, B.A, T.J. Ugye, T.D. Nyiaatagher. 2009. Chemical Composition ofmusa Sapientum (Banana) Peels,Departement of Chemistry, Benue state University, P.M.B. 102119, Makurdi

[4] Herlina, N and M. H. Ginting. 2002. Fats and Oils. USU Digital Library. University of North Sumatra. Field.

[5] Judge, M.D., E.D. Aberle, J.C. Forrest, H.B. Hendrick dan R.A. Merkel, 1989. Principle of Meat Science.2nd ed. Kendall Hunt Publishing Co. Dubuque. Iowa.

[6] Resnawati, 2004. Weight of carcass and abdominal fat from broiler broiler fed rations containing earthworm flour.

[7] R.Z.Zhong, Y. Fang, D.W. Zhou, X.Z. Sun, C.S. Zhou, Y.Q. He. 2018. Animal Feed and Technology. Volume 242, 2018, Pages 127-134

[8] Soeparno. 1998. Meat Science and Technology. UGM. Yogyakarta.

[9] Berg and Butterfield. 1976. New Concept of Cattle Growth, Sidney University Press.

[10] Ginting, D. R. 2017. Utilization of Fermented Vegetable Waste from Hair Sheep Fat Percentage. Thesis. Field. Faculty of Agriculture. University of Northern Sumatra.

[11] Purbowati, 2005. Sheep Fattening Business. Penebar Swadaya, Jakarta.

[12] Melati, I., Mulyasari, and Z. I. Azhar. 2012. The effect of fermentation using Triodherma viride and Phanerocheata chrysosporium and the combination of both of them on the composition of corn flour nutrients as raw material for fish feed. J. Ris. Aquaculture. Vol. 7. No.1. Thing. 41-47

[13] Deborah T. Crouse; Larry B. Crowder; Hal Caswell 1970. A Stage-Based Population Model for Loggerhead Sea Turtles and Implications for Conservation. Ecology, Vol. 68, No. 5. (Oct., 1987), pp. 1412-1423

[14] Soeparno. 1998. Meat Science and Technology. UGM. Yogyakarta.

[15] Frandson, R.D. 1992. Animal Anatomy and Physiology. Gadjah Mada University. Yogyakarta. 